\title{
Mechanical properties and sustainability aspects of coconut fiber modified concrete
}

\author{
Propiedades mecánicas y aspectos de sostenibilidad de concreto modificado con \\ fibras de coco
}

\author{
H. H. Gil-Sánchez iD; A. A. Zuleta-Gil iD; D. E. Reyes-Campo iD \\ DOI: https://doi.org/10.22517/23447214.22901 \\ Artículo de investigación científica y tecnológica
}

\begin{abstract}
Coir fiber has been examined for their suitability as reinforcement of concrete. Mechanical properties and sustainability aspects of concrete composites were estimated after 7. 14, and 28 days of curing. Natural reinforcement of 0.46 and $0.62 \%$ by weight of coir fiber was added. Fibers were analyzed by means of scanning electron microscope (SEM). Besides, an Eco-audit tool has been used to estimate energy and carbon emission of material, manufacturing, transportation, and disposal phases. It was found that fibers additions lowered the compressive strength compared to plain concrete. However, failures of the composites exhibited good post-cracking behavior. The use of vegetable fibers affects positively the life cycle of the material. Eco-audit results indicate that there is a potential to reduce between $9.15 \%$ and $13.35 \%$ of embodied energy and between $9.61 \%$ and $13.94 \%$ of $\mathrm{CO}_{2}$ during the material production phase. These suggest that coir fibers could be useful from the environmental view, although more studies regarding their durability are needed.
\end{abstract}

Index Terms - coir fiber, concrete, compressive strength, Ecoaudit.

Resumen-Fibras de coco han sido examinadas por su sostenibilidad como refuerzo de concreto. Propiedades mecánicas $y$ aspectos sostenibles de compuestos de concreto fueron estimadas luego de 7. 14, y 28 días de curado. Se adicionaron refuerzos naturales de 0.46 y $0.62 \%$ en peso de fibra de coco. Las fibras fueron analizadas mediante microscopía electrónica de barrido (SEM). Además, una herramienta de Eco-Auditoría se utilizó para estimar la energía y emisiones de carbono en las fases de material, manufactura, transporte y disposición. Se encontró que las adiciones de fibra disminuía la resistencia a la compresión comparado con el concreto normal. Sin embargo, las fallas de los compuestos exhibieron un buen comportamiento

This manuscript was sent on December 28, 2019 and accepted on February 05, 2021.This paragraph of the first footnote will contain the date on which you submitted your paper for review.

This work was supported by Dirección de Investigación (Proyectos de investigación sede central Politécnico colombiano Jaime Isaza Cadavid, 2016) and "Centro de Investigación para el Desarrollo y la Innovación (CIDI)" from the Universidad Pontificia Bolivariana through UPB-Innova grant 597B05/16-35.

H. Gil is with the Faculty of Engineering, Politécnico Colombiano Jaime Isaza Cadavid, Medellín, CO 050022 Colombia (e-mail: hhgil@elpoli.edu.co).

A. A. Zuleta is with Faculty of Design, Universidad Pontificia Bolivariana, Medellín, CO 050031 Colombia (e-mail: alejandro.zuleta@upb.edu.co).

D. E. Reyes is with the Faculty of Engineering, Politécnico Colombiano Jaime Isaza Cadavid, Medellín, CO 050022 Colombia (e-mail: hhgil@elpoli.edu.co). post-agrietamiento. El uso de fibras vegetales afecta positivamente el ciclo de vida del material. Los resultados de la Eco-auditoría indican que hay un potencial para reducir la energía incorporada entre $9.15 \%$ y $\mathbf{1 3 . 3 5 \%}$ y el $\mathrm{CO}_{2}$ entre $\mathbf{9 . 6 1 \%}$ y $\mathbf{1 3 . 9 4 \%}$ durante la fase de producción del material. Esto sugiere que las fibras de coco pueden ser útiles desde el punto de vista ambiental aunque son necesarios más estudios con relación a su durabilidad.

Palabras claves - fibra de coco, concreto, resistencia a la compresión, Eco-audit.

\section{INTRODUCTION}

$\mathrm{N}$ ATURAL fibers have been used in a different type of fields, especially in tropical countries where has been grown an interest in the research of their influence as reinforcing materials. The reason is that to its sustainable availability, low cost, low density, and low abrasive wear of processing machinery $[1,2]$. One of such fields is the building industry which needs of renewable sources that allow reducing environmental impacts and increasing sustainable construction.

Concrete is a material which is usually reinforced with steel bars to overcome its lack of tensile strength. However, due to the permeable behavior of concrete, the material suffers concerning carbonation and chloride ion attack resulting in corrosion problems [3, 4]. Use of natural fiber-reinforced concrete may solve the corrosion problem and also may contribute to the elaboration of low-cost composites with a low thermoacoustic transfer, low specific weight [5], improve toughness and lightweight structures [6-9]. However, one of the disadvantages of using natural fibers is their variation on mechanical properties, which could lead to unpredictable concrete features $[4,10,11]$. Different fibers have different compositions, so the behavior inside a cement matrix could differ between them $[1,2]$.

Natural fibers are mainly composed of cellulose, hemicellulose, lignin, and pectin, with small amounts of extracts [12]. Coir fibers are generally brown and are extracted from the fibrous outer shell of a coconut. The individual fiber cells are narrow and hollow, with thick walls made of cellulose [13]. Table I shows typical properties of coir fibers according to literature.

Ramaswamy et al. [18] found that vegetable fibers such as 
jute, coir, and bamboo can be used with advantage in concrete similar to other types of fibers. They also found an improvement of the impact strength and increased ductility under static loading conditions. Yan and Chouw [19] studied the effect of coir fiber inclusion and flax fiber reinforced polymer thickness on the dynamic and static properties of polymer tube confined coir fiber reinforced concrete. They found that flax fiber significantly increases axial compressive strength and ductility of the confined concrete composite.

Lecompte et al. [20] studied the use of coir fibers as reinforcement in cementitious materials, which shows that such additions modify the mechanical properties of the composite in the hardened state. The enhancement was related to both physical and chemical properties of fibers. Islam et al.

TABLE I

Properties OF COIR FIBERS

\begin{tabular}{cccccc}
\hline \hline $\begin{array}{c}\text { Density, } \\
\rho \\
\left(\mathrm{kg} / \mathrm{m}^{3}\right)\end{array}$ & $\begin{array}{c}\text { Modulus, } \\
\text { E }(\mathrm{GPa})\end{array}$ & $\begin{array}{c}\text { Tensile } \\
\text { Strength } \\
(\mathrm{MPa})\end{array}$ & $\begin{array}{c}\text { Max. } \\
\text { Deformation, } \\
\varepsilon(\%)\end{array}$ & $\begin{array}{c}\text { Moisture } \\
\text { Content } \\
\text { at } 20^{\circ} \mathrm{C} \\
(\%)\end{array}$ & $\begin{array}{c}\text { Diameter } \\
(\mu \mathrm{m})\end{array}$ \\
\hline $1177^{\mathrm{a}}$ & $4-6^{\mathrm{a}}$ & $182^{\mathrm{a}}$ & $15-25^{\mathrm{c}}$ & $10^{\mathrm{e}}$ & $300^{\mathrm{a}}$ \\
$1250^{\mathrm{c}}$ & $2.8^{\mathrm{b}}$ & $175^{\mathrm{d}}$ & $25^{\mathrm{f}}$ & $13.5^{\mathrm{f}}$ & $270^{\mathrm{e}}$ \\
$800^{\mathrm{f}}$ & $6^{\mathrm{c}}$ & $142^{\mathrm{e}}$ & & & $250^{\mathrm{f}}$ \\
& $2^{\mathrm{e}}$ & $174^{\mathrm{f}}$ & & & \\
\hline \hline
\end{tabular}

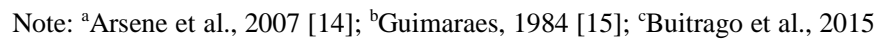
[12]; ${ }^{\mathrm{d}}$ Bisanda and Ansell, 1992 [16]; ${ }^{\mathrm{e}} \mathrm{Li}$ et al., 2006 [10]; ${ }^{\mathrm{f}}$ Toledo Filho et al., 2003 [17].

[21] study fiber-reinforced concrete mechanical properties using locally available natural fibers. They found that $0.5 \%$ and $1.0 \%$ coir fibers gives improved performance in flexural strength of the concrete also increase the ductility and toughness of concrete. Li et al. [22] also found that coir fiber reinforced cementitious composites exhibited higher energy absorbing ability and ductility than conventional cementitious materials.

Wang and Chouw [23] in a research about the behaviour of coir fiber reinforced concrete under impact loading found that the coir fiber length had an influence on the behavior of the composite specimens under repeated impact concluding that fibers with a length of $25 \mathrm{~cm}$ and $50 \mathrm{~mm}$ had better impact resistance compared with that of $75 \mathrm{~mm}$.

On the other hand, life cycle assessment (LCA) is a useful tool to be aware of the environmental burden in the entire life of the materials, through the manufacture of the product, its use, and its subsequent disposal [13]. Another approach is to limit the impact categories to energy and $\mathrm{CO}_{2}$ emission for auditing products [13]. An Eco-Audit is an initial assessment of the energy demands and carbon emissions of the life of a product $[13,24]$. The assessment is a tool to identify which phase of life has the highest environmental impact regarding energy or $\mathrm{CO}_{2}$ burden.

Sengupta et al. [25] assessed embodied greenhouse gas (GHG) emission for construction of residential buildings in India, and they found that there is ample scope of adoption of eco-friendly construction technologies for the reduction of GHG without any increase in the cost of construction. Alves et al. [1] demonstrate that natural fiber could be used as a replacement of fiberglass on automotive components after the environmental improvements estimated using LCA. It is essential to mention here that there is limited information in the literature regarding LCA studies for coir fiber reinforced concrete.

This work aims to estimate an Eco-Audit of concrete modified with coir fibers compare to plain concrete used as a reference and to contribute to the understanding of the environmental improvements regarding the use of this type of natural material. Also, laboratory experiments focusing on compressive strength were performed to obtain quantitative results to support the use of these compounds.

\section{MATERIALS AND METHODS}

Commercial Colombian coir fibers were trimmed to a maximum length of $50 \mathrm{~mm}$. Moisture content was estimated by weighing approximately $0.25 \mathrm{~g}$ of coir fiber in a RADWANG PMR $210 \mathrm{WH}$ moisture analyzer balance with an uncertainty of $1 \mathrm{mg}$. The fibers were subsequently, dried out in the balance from room temperature until $105^{\circ} \mathrm{C}$, and then it was maintained until the stabilization of weight was reached. A total of four independent moisture estimations were carried out. A scanning electron microscope (SEM) with JEOL JSM2490 CV device equipped with energy dispersive X-ray (EDX) spectroscopy (OXFORD INCAPentaFET-x3) was used to perform morphological observations on untreated coir fiber.

The specimens were made with 0.46 and $0.62 \%$ (w/w of cement) of coir fibers. The composite mix was designed using plain concrete with a ratio of cement, sand, and aggregates of 1:2:4 by weight, respectively. The water-cement ratio (w/c) used was of 0.6. After mixing ceramic components for 10 minutes, coir fibers were slowly dosed to guarantee the right mixing conditions avoiding fiber agglomeration. A SIKAPlast 5000 superplasticizer was used to improve the rheological properties of the concrete, increasing the workability of the mix. A ratio of superplasticizer/cement of 0.015 was used. Then, the composites were poured into cylindrical steel molds of $15 \mathrm{~mm}$ of diameter and $30 \mathrm{~mm}$ height. For each layer of composite, it was used 25 strikes following the procedure described in ASTM standard C39. After that, the composited were allowed to settle for three days at $25^{\circ} \mathrm{C}$. Then, the samples were removed from the molds and located inside a curing water tank. For each composite sample, it was performed a density measure and a compressive test. 
All cylinders were tested in an ADR 1000 compression testing machine at $25 \pm 0.05 \mathrm{MPa} / \mathrm{s}$ to determine compressive strength $(\sigma)$ after 7. 14, and 28 days of curing. Triplicate samples were used for each composite. Three additional samples without any natural fiber were tested after 28 days of curing for comparison purposes.

Assess of energy (MJ) and CO2 $(\mathrm{kg})$ emission of material, manufacturing, transportation, and disposal phases (Eco-audit) was performed. The use phase was not taking into account because a study of the durability of coir fiber inside a concrete environment is needed. Studies are currently on-going in the author's laboratory to estimate coir fiber degradation in alkaline environments.

\section{RESULTS AND DISCUSSION}

\section{A. Moisture content}

An average of $13.82 \% \pm 0.159$ of moisture content was found on the fibers. The reported value is entirely closed to the reported by Toledo Filho et al. [17] (See Table 1). According to the literature [26, 27], coir fibers have a low affinity with water due to a high quantity of lignin. In this study, the coir fibers were pre-soaked in water before mixing to avoid workability problems.

\section{B. Morphological observations}

An average of $13.82 \% \pm 0.159$ of moisture content was found on the fibers. The reported value is entirely closed to the reported by Toledo Filho et al. [17] (See Table I). According to the literature [26, 27], coir fibers have a low affinity with water due to a high quantity of lignin. In this study, the coir fibers were pre-soaked in water before mixing to avoid workability problems.

Fig. 1. The image exhibits a surface with a slightly rough exterior, which suggests that coir could have excellent adhesion with the concrete. The protrusions on the fibers can also offer extra anchoring points such that the fiber can withstand stresses from the matrix ( $\mathrm{Li}$ et al., 2006) and even higher contact area. Fibers have an average diameter of 391 $\mu \mathrm{m}$, which is similar to the one reported in the literature (see Table I. Surface pits can also be seen in Figure 1. Same morphology results have been published before by Rout et al. [28] and John et al. [9].

According to the EDX analysis, carbon and oxygen are detected on the fibers. Most of the pits seen on the fibers exhibit silicon occlusions (white dots in Figure 1) in agreement with the results of John et al. [9] and Anggraini et al. [29]. The authors suggest that pits are filled with fatty substances that hold the unit cells in the fiber. According to Calado et al. [30] when the outer layer of the fiber is removed, a rougher, and more ordered structure is revealed with white dots on the surface as it is seen in this investigation. The silica-rich material has been identified as tyloses, and it is evidence that the fibers were not over treated [31]. In this work, the presence of silicon was confirmed employing EDX, as can be seen in Fig. 2. The local spectrums were taken in two different points on the surface: inside the white dot

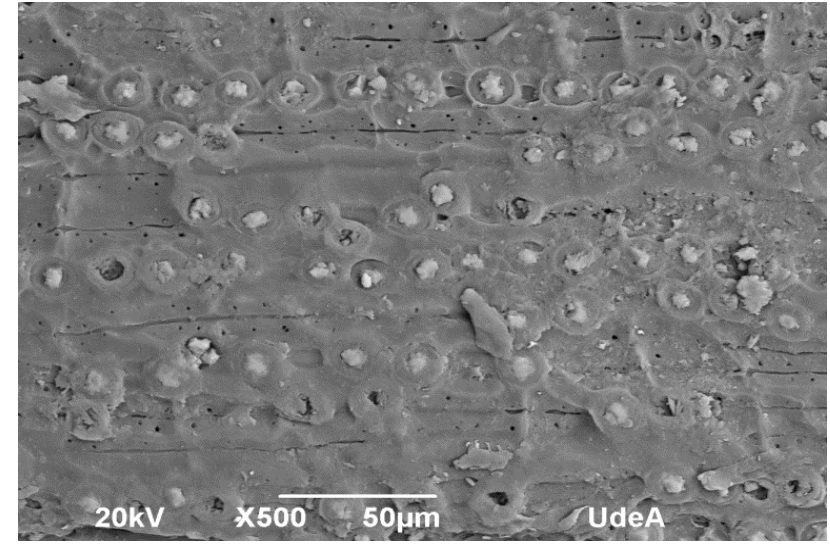

Fig. 1. SEM micrograph of the surface morphology of coconut fiber.

(Spectrum 1 in Fig. 2b) and outside the pits (Spectrum 2 in Fig. 2c). Fra) the SEM micrographs could be expected that composites have good mechanical behavior between the fiber and the cement matrix.

\section{Visual appearance}
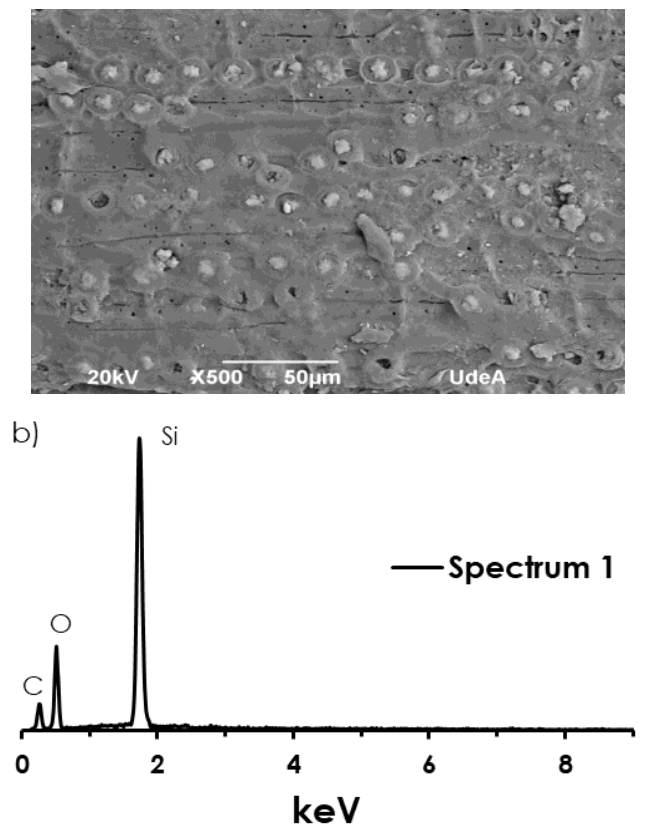

c)

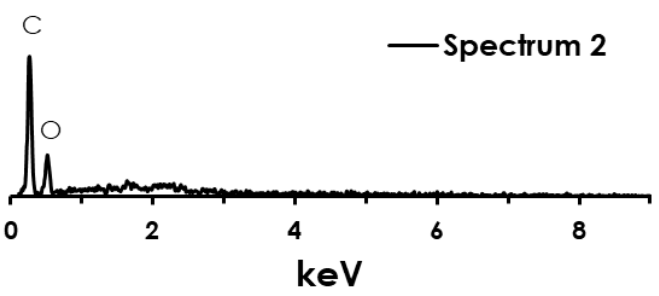

Fig. 2. SEM micrograph of coconut fiber from (a) external wall and EDX results for two different local spectrums from (b) inside the white dot and (c) outside the pits.

Fig. 3a-b shows the visual appearance of tested composites 
after 28 days of curing for 1 and $3 \%$ of coir fiber, respectively.

As can be seen, the structure is held by the coir fibers avoiding total failure of the cylinders. The fiber reinforced concrete remained in one piece retaining their shape and continuity. As increase the fiber content, the cracks due to the compressive test diminish.

\section{Compressive test and density}

Fig. 4 shows the behavior of composites with and without
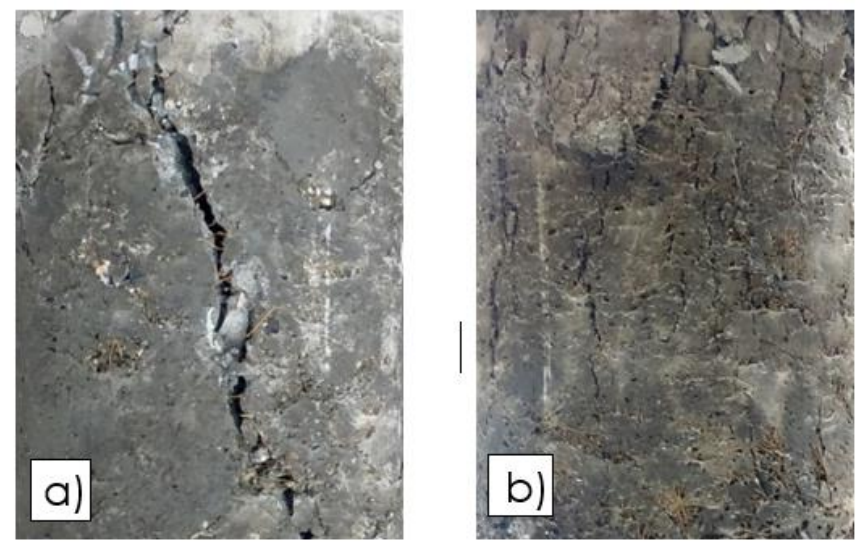

Fig. 3. Visual appearance of concrete samples after failure for a) $0.46 \%$ and b) $0.62 \%$ or coconut fiber content.

coir fiber against curing time. The results are the average values obtained after each sample fails by compression. There is no statistical difference for early curing time as can be seen from the error bars. Standard deviation is lower for little fiber content, but when it is increased, the variation is more significant which could be associated with some agglomeration of the fiber during the preparation of the samples, and it was more pronounced for $0.62 \%$ of coir fiber. However, plain concrete evidence even larger error bars which could be associated to be within the equipment error.

After 28 days of curing time, samples with fiber contents exhibit lower compressive strength than the blank sample. Also, more considerable resistance was observed for $0.62 \%$ fiber reinforced concrete compared to $0.46 \%$ of fiber content. Nevertheless, in both cases, continuous growth in strength is found. These could be interpreted due to the water which had

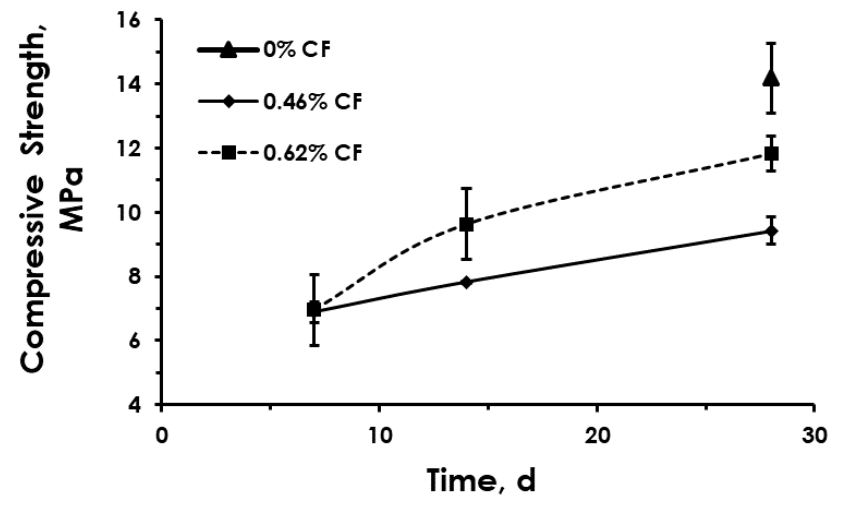

Fig. 4. Composites compressive strength after 7, 14, and 28 days of water curing with different coconut fiber content. been absorbed by the fibers is available for further hydration of cement after 28 days of curing [18]. Another possibility is that incorporation of fibers reduces shrinkage and as a consequence inhibits some micro-craking formation. The maximum strength of composites is reached for $0.62 \%$ coir fiber with approximately $11.84 \mathrm{MPa}$ after 28 days of curing. However, in any case, it is lower than un-reinforced concrete.

Experimental compressive strength was compared to theoretical values estimated using (1) [32, 33]:

$$
E_{c f}=3830 \sqrt{f_{c f}}+10^{5} V_{f}
$$

Where Ecf is Young's modulus, fcf is the uniaxial compressive strength of concrete and $\mathrm{Vf}$ is the volume fraction of the fiber. Young's modulus was obtained by using a synthesizer tool of CES EduPack 2016. An error percentage for the average compressive strength of 7.53, 21.81, and $14.80 \%$ was found for concrete with $0,0.46$ and $0.62 \%$ (wt.) of coir fiber, respectively.

Regarding the degradation of natural fibers immersed in Portland cement, it is known that the high alkaline environment dissolves the lignin and hemicellulose phases [4]. The dissolution can cause the weakening the fiber structure [34]. These could explain that the ultimate strength reached by the composites is lower than expected. Although in this study coir fibers evidence some stability after 28 days of curing, it is necessary to perform a surface treatment on the fibers to improve their strength and durability.

Figure 5 shows density variation against curing time for all samples. Coir fiber concretes exhibited lower densities compared to plain concrete specimens. However, according to the scattering data, there is no statistical difference between vegetable fiber concretes with $0.46 \%$ and $0.62 \%$ of coir fiber. Density reductions of $9.56 \%$ and $13.87 \%$ were reached compared to the plain concrete after 28 of curing for 0.46 and $0.62 \%$ of coir fiber respectively. These could be an advantage from the sustainability point of view regarding diminishing of energy and carbon footprint (see eco-audit results below).

The increase in the volume of the composites is related to the rise of natural fiber [35] and the results exhibited in Fig 5

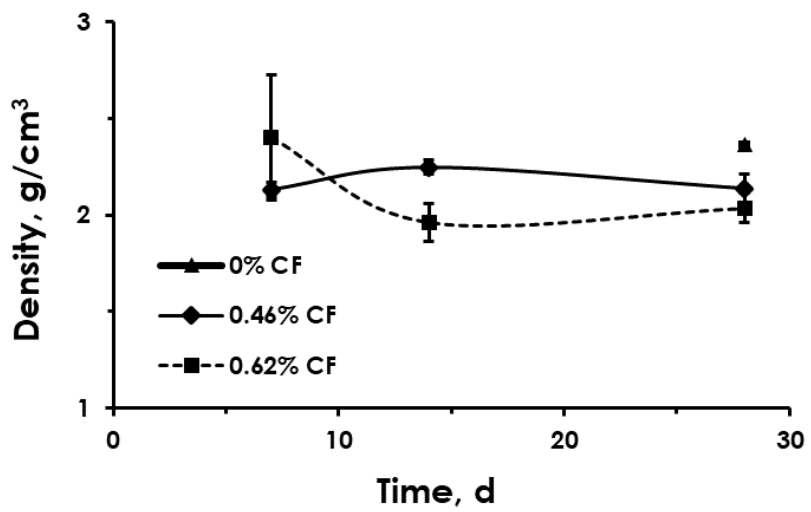

Fig. 5. Density for different coconut fiber content after 7, 14, and 28 days of water curing. 
are in agreement with that statement and previously reported density values of cement composites which decreases with the increasing content of natural fiber [36].

\section{E. Eco-audit}

Microsoft Excel software was used to estimate the EcoAudit of the composites, and the following conditions were used. A volume of $1 \mathrm{~m} 3$ was considered for each composite, and the density values after 28 days of curing were of 2364 $\mathrm{kg} / \mathrm{m} 3,2138 \mathrm{~kg} / \mathrm{m} 3$ and $2036 \mathrm{~kg} / \mathrm{m} 3$ for plain, $0.46 \%$ CF and $0.62 \% \mathrm{CF}$, respectively. For material phase, it was used an embodied energy and carbon footprint for primary production of each component of the composites from Table II The manufacture of Portland cement is usually made by two different methods, wet and dry processes with different embodied energy associated [37]. In this case, an average of $6.15 \mathrm{MJ} / \mathrm{kg}$ has been used. Embodied energy for crushed stone and sand were chosen to be 0.137 and $0.064 \mathrm{MJ} / \mathrm{kg}$, respectively. The origin of the raw material was the same place as the construction site. A value of $7.58 \mathrm{MJ} / \mathrm{kg}$ of embodied energy for primary production of coir fiber was used [13]. $\mathrm{CO}_{2}$ footprint for each material was calculated according to average values in Table II.

For manufacturing phase, the estimation was focused on primary production with embodied energy values of 0.02 $\mathrm{MJ} / \mathrm{kg}$ and $2.605 \mathrm{MJ} / \mathrm{kg}$ and carbon footprint of $0.002 \mathrm{~kg} / \mathrm{kg}$ and $0.208 \mathrm{~kg} / \mathrm{kg}$ for concrete and coir fiber respectively [13]. For all systems, it was assumed that the construction energy of concrete would be the same. Transportation phase was assessed by considering a $100 \mathrm{~km}$ distant following the methodology of an environmental product declaration [43]. A 14-metric ton truck was used for all assessment with an embodied energy of $0.85 \mathrm{MJ} / \mathrm{kg}$ and carbon footprint of 0.11 $\mathrm{kgCO}_{2} /$ metric ton.km [13]. Disposal phase was considered to be landfill in all cases, as is more usual in the region of study (Colombia) with recollection energy of $0.2 \mathrm{MJ} / \mathrm{kg}$ and carbon footprint of $0.07 \mathrm{~kg} / \mathrm{kg}$ [13].

Figure 6 shows the energy results for the composites. The more significant contribution of energy is related to the production of the material that is used to make the composites, following by disposal, transport, and manufacturing phase. Energy demand for material phase is nearly 49,45 , or 44 times

TABLE II

EMBODIED ENERGY AND $\mathrm{CO}_{2}$ FOOTPRINTS OF THE MATERIALS

\begin{tabular}{ccc}
\hline \hline Material & $\begin{array}{c}\text { Embodied energy } \\
(\mathrm{MJ} / \mathrm{kg})\end{array}$ & $\begin{array}{c}\mathrm{CO}_{2} \text { footprint } \\
(\mathrm{kg} / \mathrm{kg})\end{array}$ \\
\hline Cement & $4.6-7.7^{\mathrm{a}-\mathrm{f}}$ & $0.83^{\mathrm{e}}-1.05^{\mathrm{a}}$ \\
Aggregate & $0.124-0.15^{\mathrm{c}, \mathrm{f}}$ & $0.005^{\mathrm{g}}$ \\
Sand & $0.0285-0.1^{\mathrm{d}, \mathrm{f}-\mathrm{g}}$ & $0.005^{\mathrm{g}}$ \\
Coir fiber & $7.58^{\mathrm{h}}$ & $0.45^{\mathrm{h}}$ \\
\hline \hline
\end{tabular}

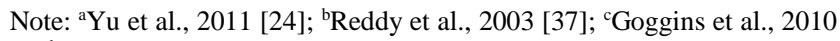
[38]; ${ }^{\mathrm{d} K o f o w o r o l a ~ e t ~ a l ., ~} 2009$ [39]; ${ }^{\mathrm{e}} \mathrm{Hammond}$ and Jones, 2008 [40]; ${ }^{f}$ Gonzalez et al., 2009 [41];:Baird and Alcorn, 1997 [42]; Ashby, 2012 [13]. more than for the manufacturing phase for $0,0.46$ and $0.62 \%$ of $\mathrm{CF}$ respectively. This result is the most extreme regarding the comparison with any other stages, which means that the Eco-Aware design regarding materials choice should be prioritized with the replacement of cement or aggregates with low-energy materials, such as natural fibers. The energy of the material phase was found to represent around $76 \%$ of the total energy for all composites.

The use of coir fiber as a replacement for cement produces a decrease of $191 \mathrm{MJ}$ and $278 \mathrm{MJ}$ in material energy for $0.46 \%$ and $0.62 \%$ coir fiber respectively. On the other hand, transportation and disposal phases are also linked to the choice of the material which means that there is a potential to reduce

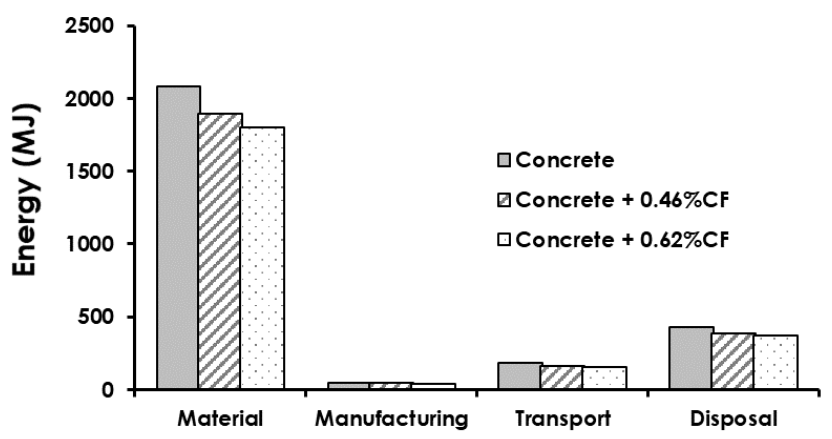

Fig. 6. Embodied energy of the different fiber content composites.

energy and carbon emissions with lightweight concrete and recycling to recover energy at the end of the life. Disposal type selection also plays an essential role in energy and carbon emissions, especially for concrete, which could be recycled as aggregate in other types of composites.

$\mathrm{CO}_{2}$ footprint follows the same trend as energy as can be seen in Fig. 7. Savings of carbon emission during the material phase are close to 28 and $40 \mathrm{~kg}$ for $0.46 \%$ and $0.62 \%$ of coir fiber respectively. The carbon footprint of the material phase was found to represent around $83 \%$ of the total $\mathrm{CO} 2$ emitted for all composites. In general, the embodied energy or $\mathrm{CO}_{2}$ footprint on a volumetric basis increases with the increasing density.

The outcome of the global Eco-audit indicates that there is a potential to reduce between $9.15 \%$ and $13.35 \%$ of the embodied energy and between $9.61 \%$ and $13.94 \%$ of carbon emission during the production of the material necessary to

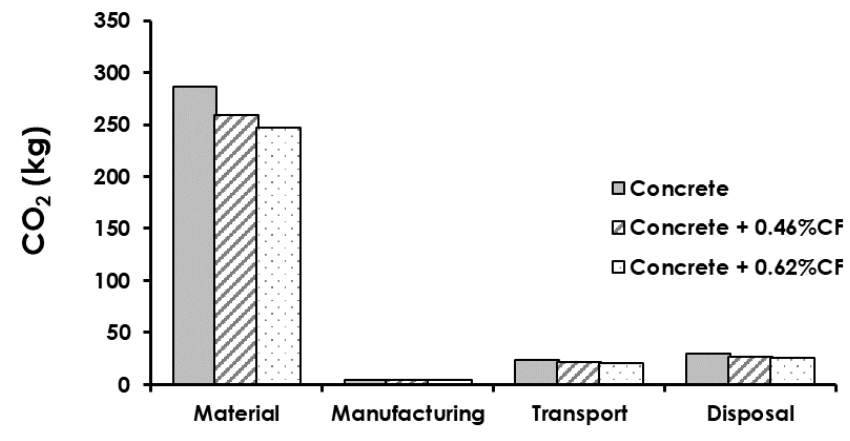

Fig. 7. Carbon emission of the different fiber content composites 
build the composites. Coir fiber has the advantage related to their renewable nature and its high output in local sourcing. Also, the effect of reinforcing concrete matrix causes a more flexible behavior, which can be an advantage to absorb energy in lightweight structures.

\section{CONCLUSIONS}

The results of different experiments with coir fiber reinforced concrete shows that this type of vegetable fiber can be used with some advantages in concrete and can be lead to the following conclusions:

1. Coir fiber exhibits good mechanical response as aggregate to concrete composite due to post-crack load bearing capacity. Failure of modified composites seems less drastic than plain concrete due to the additional toughness produced by the coir fibers.

2. As increase coir fiber volume inside composite the more compressive strength is obtained. After 28 days of water curing composites with $0.46 \%$ and $0.62 \%$ fiber produces a compressive resistance of $9.43 \mathrm{MPa}$ and $11.84 \mathrm{MPa}$ respectively. However, both values are below the plain concrete.

3 . The use of natural reinforcement affects positively to all life cycle of the material, especially for material and disposal phase. Coir fiber composites exhibit lower embodied energy and carbon emissions showing a potential to reduce between $9.15 \%$ and $13.35 \%$ and between $9.61 \%$ and $13.94 \%$, respectively.

\section{ACKNOWLEDGMENT}

This work was supported by Dirección de Investigación (Proyectos de investigación sede central Politécnico colombiano Jaime Isaza Cadavid, 2016) and "Centro de Investigación para el Desarrollo y la Innovación (CIDI)" from the Universidad Pontificia Bolivariana through UPB-Innova grant 597B-05/16-35.

\section{REFERENCES}

[1] C. Alves et al., "Ecodesign of automotive components making use of natural jute fiber composites," Journal of Cleaner Production, vol. 18, no. 4, pp. 313-327, Mar. 2010.

[2] D. Mulinari, C. Baptista, J. Souza, and H. Voorwald, "Mechanical properties of coconut fibers reinforced polyester composites," Procedia Engineering, vol. 10, pp. 2074-2079, 2011.

[3] F. P. Glasser, J. Marchand, and E. Samson, "Durability of concrete - degradation phenomena involving detrimental chemical reactions," Cement and Concrete Research, vol. 38, no. 2, pp. 226246, 2008.

[4] F. Pacheco-Torgal and S. Jalali, "Cementitious building materials reinforced with vegetable fibres: A review," Construction and Building Materials, vol. 25, no. 2, pp. 575-581, Feb. 2011.

[5] E. J. da Silva, M. L. Marques, F. G. Velasco, C. F. Junior, F. M. Luzardo, and M. M. Tashima, "A new treatment for coconut fibers to improve the properties of cement-based composites-Combined effect of natural latex/pozzolanic materials," Sustainable Materials and Technologies, vol. 12, pp. 44-51, 2017.

[6] L. Aggarwal, "Studies on cement-bonded coir fibre boards," Cement and Concrete Composites, vol. 14, no. 1, pp. 63-69, 1992.
[7] S. Al-Oraimi and A. Seibi, "Mechanical characterisation and impact behaviour of concrete reinforced with natural fibres," Composite Structures, vol. 32, no. 1-4, pp. 165-171, 1995.

[8] M. Aziz, P. Paramasivam, and S. Lee, "Concrete reinforced with natural fibres," Concrete technology and design, vol. 2, pp. 106$140,1984$.

[9] V. John, M. Cincotto, C. Sjöström, V. Agopyan, and C. Oliveira, "Durability of slag mortar reinforced with coconut fibre," Cement and Concrete Composites, vol. 27, no. 5, pp. 565-574, 2005.

[10] Z. Li, L. Wang, and X. Wang, "Flexural characteristics of coir fiber reinforced cementitious composites," Fibers Polym, vol. 7, no. 3, pp. 286-294.

[11] H. S. Sobral, Vegetable Plants and Their Fibres as Building Materials: Proceedings of the Second International RILEM Symposium. Routledge, 2004.

[12] B. Buitrago, F. Jaramillo, and M. Gómez, "Some Properties of Natural Fibers (Sisal, Pineapple, and Banana) in Comparison to Man-Made Technical Fibers (Aramide, Glass, Carbon)," Journal of Natural Fibers, vol. 12, no. 4, pp. 357-367, Jul. 2015.

[13] M. F. Ashby, Materials and the Environment: Eco-informed Material Choice. Elsevier, 2012.

[14] M.-A. Arsène, H. Savastano Jr, S. M. Allameh, K. Ghavami, and W. O. Soboyejo, "Cementitious composites reinforced with vegetable fibers," presented at the Anais da 1st INTER AMERICAN CONFERENCE ON NONCONVENTIONAL MATERIALS AND TECHNOLOGIES IN THE ECOCONSTRUCTION AND INFRASTRUCTURE. João Pessoa$\mathrm{PB}, 2003$.

[15] S. da S. Guimarães, "Experimental mixing and moulding with vegetable fibre reinforced cement composites," presented at the International Conference on Development of Low-Cost and Energy Saving Construction Materials, 1984, pp. 37-42.

[16] E. Bisanda and M. P. Ansell, "Properties of sisal-CNSL composites," Journal of Materials Science, vol. 27, no. 6, pp. 1690-1700, 1992.

[17] R. D. Toledo Filho, K. Ghavami, G. L. England, and K. Scrivener, "Development of vegetable fibre-mortar composites of improved durability," Cement and concrete composites, vol. 25, no. 2, pp. 185-196, 2003.

[18] H. S. Ramaswamy, B. M. Ahuja, and S. Krishnamoorthy, "Behaviour of concrete reinforced with jute, coir and bamboo fibres," International Journal of Cement Composites and Lightweight Concrete, vol. 5, no. 1, pp. 3-13, Feb. 1983.

[19] L. Yan and N. Chouw, "Dynamic and static properties of flax fibre reinforced polymer tube confined coir fibre reinforced concrete," Journal of Composite Materials, vol. 48, no. 13, pp. 1595-1610, Jun. 2014.

[20] T. Lecompte, A. Perrot, A. Subrianto, A. Le Duigou, and G. Ausias, "A novel pull-out device used to study the influence of pressure during processing of cement-based material reinforced with coir," Construction and Building Materials, vol. 78, pp. 224233, 2015.

[21] S. M. Islam, R. R. Hussain, and M. A. Z. Morshed, "Fiberreinforced concrete incorporating locally available natural fibres in normal- and high-strength concrete and a performance analysis with steel fibre reinforced composite concrete," Journal of Composite Materials, vol. 46, no. 1, pp. 111-122, 2012.

[22] Z. Li, L. Wang, and X. Wang, "The long-term performance of cementitious composites reinforced with coir fibre," Journal of The Textile Institute, vol. 103, no. 8, pp. 912-920, 2012.

[23] W. Wang and N. Chouw, "The behaviour of coconut fibre reinforced concrete (CFRC) under impact loading," Construction and Building Materials, vol. 134, pp. 452-461, 2017.

[24] D. Yu, H. Tan, and Y. Ruan, "A future bamboo-structure residential building prototype in China: Life cycle assessment of 
energy use and carbon emission," Energy and Buildings, vol. 43, no. 10, pp. 2638-2646, Oct. 2011.

[25] N. Sengupta, S. Roy, and H. Guha, "Assessing embodied GHG emission reduction potential of cost-effective technologies for construction of residential buildings of Economically Weaker Section in India," Asian J Civ Eng, vol. 19, no. 2, pp. 139-156, Feb. 2018.

[26] L. Q. N. Tran, C. A. Fuentes, C. Dupont-Gillain, A. W. Van Vuure, and I. Verpoest, "Understanding the interfacial compatibility and adhesion of natural coir fibre thermoplastic composites," Composites Science and Technology, vol. 80, pp. 23-30, May 2013.

[27] L. Yang and J. Thomason, "Development and application of micromechanical techniques for characterising interfacial shear strength in fibre-thermoplastic composites," Polymer Testing, vol. 31, no. 7, pp. 895-903, 2012.

[28] J. Rout, S. Tripathy, M. Misra, and A. Mohanty, "Scanning electron microscopy study of chemically modified coir fibers," Journal of Applied Polymer Science, vol. 79, no. 7, pp. 11691177, 2001.

[29] V. Anggraini, A. Asadi, B. B. Huat, and H. Nahazanan, "Effects of coir fibers on tensile and compressive strength of lime treated soft soil," Measurement, vol. 59, pp. 372-381, 2015.

[30] V. Calado, D. Barreto, and J. d'Almeida, "The effect of a chemical treatment on the structure and morphology of coir fibers," Journal of Materials Science Letters, vol. 19, no. 23, pp. 2151-2153, 2000.

[31] S. Prasad, C. Pavithran, and P. Rohatgi, "Alkali treatment of coir fibres for coir-polyester composites," Journal of Materials Science, vol. 18, no. 5, pp. 1443-1454, 1983.

[32] A. A. Abdul-Razzak and A. A. M. Ali, "Modelling and numerical simulation of high strength fibre reinforced concrete corbels," Applied Mathematical Modelling, vol. 35, no. 6, pp. 2901-2915, 2011.

[33] S. A. Ashour, F. F. Wafa, and M. I. Kamal, "Effect of the concrete compressive strength and tensile reinforcement ratio on the flexural behavior of fibrous concrete beams," Engineering Structures, vol. 22, no. 9, pp. 1145-1158, 2000.

[34] H.-E. Gram, "Durability of natural fibres in concrete," SAREC Report (Sweden), 1984.

[35] N. I. M. Nadzri, S. B. Jamaludin, and M. M. Noor, "Development and properties of coconut fiber reinforced composite cement with the addition of fly ash," Journal of Sustainable Cement-Based Materials, vol. 1, no. 4, pp. 186-191, 2012.

[36] M. N. Mazlee, B. J. Shamsul, and H. Kamarudin, "Composite cement reinforced coconut fiber: physical and mechanical properties and fracture behavior," 2011.

[37] B. V. Reddy and K. Jagadish, "Embodied energy of common and alternative building materials and technologies," Energy and buildings, vol. 35, no. 2, pp. 129-137, 2003.

[38] J. Goggins, T. Keane, and A. Kelly, "The assessment of embodied energy in typical reinforced concrete building structures in Ireland," Energy and Buildings, vol. 42, no. 5, pp. 735-744, 2010.

[39] O. F. Kofoworola and S. H. Gheewala, "Life cycle energy assessment of a typical office building in Thailand," Energy and Buildings, vol. 41, no. 10, pp. 1076-1083, 2009.

[40] G. Hammond, C. Jones, F. Lowrie, and P. Tse, Inventory of carbon \& energy: ICE. Sustainable Energy Research Team, Department of Mechanical Engineering, University of Bath Bath, 2008.

[41] M. A. Gonzalez Stumpf, M. Piva Kulakowski, L. G. Breitenbach, and F. Kirch, "A case study about embodied energy in concrete and structural masonry buildings," Revista de la Construcción, vol. 13, no. 2, 2014.

[42] G. Baird, A. Alcorn, and P. Haslam, "The energy embodied in building materials-updated New Zealand coefficients and their significance," Transactions of the Institution of Professional
Engineers New Zealand: Civil Engineering Section, vol. 24, no. 1, p. 46, 1997.

[43] C. Strazza, A. D. Borghi, G. A. Blengini, and M. Gallo, "Definition of the methodology for a Sector EPD (Environmental Product Declaration): case study of the average Italian cement," Int J Life Cycle Assess, vol. 15, no. 6, pp. 540-548, May 2010. 